\title{
The antihyperglycemic effect of Bridelia ndellensis ethanol extract and its fractions is mediated by an insulinotropic action
}

\author{
Selestin Dongmo Sokeng ${ }^{1^{\star}}$, Begum Rokeya $^{2}$, Jamadder Mohammed Abdul Hannan ${ }^{3}$, \\ Liaquat $\mathrm{Ali}^{2}$, Pierre Kamtchouing ${ }^{4}$ \\ ${ }^{1}$ Department of Biological Sciences, University of Ngaoundéré, Ngaoundéré, Cameroon; \\ *Corresponding Author: dsokeng@yahoo.com \\ ${ }^{2}$ Research Division, Bangladesh Institute of Research and Rehabilitation in Diabetes, Endocrine and Metabolic Disorders (BIRDEM), \\ Dhaka, Bangladesh \\ ${ }^{3}$ Department of Pharmacy, North South University, Dhaka, Bangladesh \\ ${ }^{4}$ Laboratory of Animal Physiology, Faculty of Science, University of Yaounde, Yaounde, Cameroon
}

Received 30 April 2013; revised 1 June 2013; accepted 10 June 2013

Copyright (C) 2013 Selestin Dongmo Sokeng et al. This is an open access article distributed under the Creative Commons Attribution License, which permits unrestricted use, distribution, and reproduction in any medium, provided the original work is properly cited.

\section{ABSTRACT}

Backgroung: Bridelia ndellensis (Euphorbiaceae) is used as a traditional plant treatment of diabetes. The aim of the present study was to investigate the mechanism involved in the antihyperglycemic effects of this plant. Methods: An intestinal perfusion technique was used to study the effect of the ethanol extract of $B$. ndellensis on the intestinal absorption of glucose in normal rats fasted for $36 \mathrm{~h}$. The effect of the extract (50 and $100 \mathrm{mg} / \mathrm{kg}$ ) on Insulin secretion was evaluated using BRIN-BD11 pancreatic cells. Results: In a perfused rat intestinal preparation in situ, the plant extract at a concentration of $5 \mathrm{mg} / \mathrm{ml}$ did not show any inhibitory effects on glucose absorption when compared with control animals. Ouabain which is an inhibitor of glucose transport across the small intestine significantly $(p<$ 0.001 ) decreased the glucose absorption during the whole perfusion period compared with the control group. On the other hand, the plant extract inhibited the gastrointestinal motility induced by Barium sulphate milk in rats. The ethanol extract of $B$. ndellensis at concentrations of 50 and $100 \mu \mathrm{g} / \mathrm{ml}$ stimulated in a concentration-dependent manner the insulin secretion from BRIN-BD11 cells in vitro. The induction of insulin release was significantly different when compared to control with the concentration of $100 \mu \mathrm{g} / \mathrm{ml}(P<0.001)$. Alanine $(10 \mathrm{mM})$ used as positive control, significantly $(p<0.001)$ stimulated insulin release from BRIN-BD11 cells. Conclusion: The present study has revealed that B. ndellensis ethanol extract stimulates insulin secretion and does not affect the glucose absorption, and it has suggested that the antihyperglycemic effects of $B$. ndellensis is partly mediated by the stimulation of insulin secretion.

Keywords: Bridelia ndellensis; Ethanol Extract; Intestinal Glucose Absorption; Insulin Secretion in Vitro

\section{INTRODUCTION}

Diabetes is a serious chronic metabolic disorder that has a significant impact on the health, quality of life and life expectancy of patients, as well as on the health care system [1]. Treatments aimed at enhancing b-cell function and reducing insulin resistance are therefore key to improving metabolic control and retarding the development of diabetic complications. At least 250 million individuals worldwide suffer diabetes and it is estimated that by 2030 this number will double [2]. Diabetes is one of the top five most significant diseases in the developed world. Based on WHO recommendations, anti-diabetic agents of plant origin are important for use in traditional medicine [3]. It is estimated that about $75 \%$ of the world's population relies on plant medicines [4]. Few of the plant treatments used traditionally for diabetes have received scientific scrutiny [5,6], and the World Health Organization (WHO) recommended accordingly that this area warrants more attention [7]. 
Bridelia ndellensis Beille is a plant belonging to $\mathrm{Eu}-$ phorbiaceae family. This medicinal plant is commonly used in Cameroon against fever, rheumatism, diarrhoea, and diabetes. Recently, we reported the hypoglycemic and antihyperglycemic effects of B. ndellensis ethanol extract and its fractions in streptozotocin-induced diabetic rats [5]. However, the mechanism of action of this plant extract has not yet been elucidated.

The present study was therefore undertaken to investigate the anti-diabetic actions of $B$. ndellensis ethanol extract on insulin secretion in vitro and glucose absorption using a perfused rat intestinal preparation.

\section{MATERIALS AND METHODS}

\subsection{Collection of Plant Material}

B. ndellensis stem bark was collected from Ngaoundere, Adamawa Region, Cameroon. Botanical identification was performed at the national herbarium, Yaounde, Cameroon and herbarium voucher specimen number 9676/HNC has been deposited. Bark samples were dried under sunlight and powdered.

\subsection{Extraction Procedure and Fractionation}

A $2.5 \mathrm{~kg}$ powdered B. ndellensis bark was extracted (4 times, 24 hours each time) with $80 \%$ ethanol at room temperature, filtered and concentrated in vacuo $\left(40^{\circ} \mathrm{C}\right)$ and freeze-dried to obtain a $200 \mathrm{~g}$ extract $(8 \% \mathrm{w} / \mathrm{w})$ using a Varian 801-model LY-3-TT freeze-dryer (USA).

\subsection{Animals}

Male Long-Evans rats (200 - $230 \mathrm{~g})$ bred at BIRDEM laboratory, Bangladesh, were used for this study. The animals were maintained on 12 hours light-dark cycle at room temperature, fed on a standard laboratory pellet diet and with water supplied ad libitum.

\subsection{Plant Extracts Effect on Intestinal Glucose Absorption}

An intestinal perfusion technique [8] was used to study the effect of the ethanol extract of $B$. ndellensis on the intestinal absorption of glucose in normal rats fasted for $36 \mathrm{~h}$ and anesthetized with sodium pentobarbital $(50 \mathrm{mg} /$ $\mathrm{kg})$. The plant extracts were added to a Kreb solution $(\mathrm{g} / \mathrm{l}$, $1.02 \mathrm{CaCl}_{2}, 7.37 \mathrm{NaCl}, 0.20 \mathrm{KCl}, 0.065 \mathrm{NaH}_{2} \mathrm{PO}_{4} \cdot 6 \mathrm{H}_{2} \mathrm{O}$, $\left.0.6 \mathrm{NaHCO}_{3}, \mathrm{pH} 7.5\right)$, supplemented with glucose (54.0 $\mathrm{g} / \mathrm{l}$ ) and perfused through the pyloric entry of duodenum at a perfusion rate of $0.5 \mathrm{ml} / \mathrm{min}$ for $30 \mathrm{~min}$ through the duodenum. The perfusate was collected from a catheter set at $40 \mathrm{~cm}$. The plant extracts were added to Kreb solution to a final concentration of $5 \mathrm{mg} / \mathrm{ml}$ for $B$. ndellensis extract, so that the amount of extract in the perfused intestine be equivalent to $250 \mathrm{mg} / \mathrm{kg}$. The control group was perfused only with Kreb solution supplemented with glucose. The effect of ouabain $(1 \mathrm{mmol} / \mathrm{l}$ in Kreb solution) a known inhibitor of glucose absorption, was tested in a similar manner [9]. Glucose concentration was estimated by the glucose oxidase method using a commercial kit from Sera Pak, USA. The results were expressed as percentage of absorbed glucose, calculated from the amount of glucose in solution before and after the perfusion.

\subsection{Effect of the Plant Extracts on Gastrointestinal Motility}

Gastrointestinal motility was evaluated using Barium sulphate milk as previously described by [10]. $\mathrm{BaSO}_{4}$ milk was prepared by adding $\mathrm{BaSO}_{4}$ as $10 \% \mathrm{w} / \mathrm{v}$ in $0.5 \%$ carboxymethyl cellulose (CMC) suspension. The milk was given orally $1 \mathrm{~h}$ after administration of the extract to normal rats fasted for $36 \mathrm{~h}$. Distilled water $(10 \mathrm{ml} / \mathrm{kg}$, bw) was given to control rats prior to $\mathrm{BaSO}_{4}$ administration by oral feeding. Treated and control rats were sacrificed 15 min after milk administration. The distance traversed by $\mathrm{BaSO}_{4}$ milk was measured and expressed as a percentage of the total length of small intestine (from pylorus to the ileo-ceccal junction).

\subsection{Assessment of the Insulinotropic Action of B. ndellensis Ethanol Extract}

Insulin secretion was evaluated using monolayers of BRIN-BD11 clonal pancreatic cells [10]. BRIN-BD11 cells were routinely cultured in Roswell Park Memorial Institute (RPMI) 1640 tissue culture medium containing $11.1 \mathrm{mM}$-glucose, $10 \%$ fetal calf serum and antibiotics (50,000 IU/1 penicillin-streptomycin). Cell monolayers were maintained in $25 \mathrm{ml}$ of tissue culture medium in 75 $\mathrm{cm}^{2}$ sterile vented tissue culture flasks (Corning Incorp., New York) at $37^{\circ} \mathrm{C}$ in an atmosphere of $5 \% \mathrm{CO}_{2}$ in air using a LEEC incubator (Laboratory Technical Engineering, Nottingham). BRIN-BD11 cells were harvested using trypsin, resuspended in culture medium and seeded in each well of 24-well multiplate at a density of $0.15 \times$ 106 cells per well. Following overnight culture at $37^{\circ} \mathrm{C}$ to allow attachment of cells, the culture medium was removed and $1 \mathrm{ml}$ Krebs-Ringer bicarbonate buffer (KRB; $115 \mathrm{mM} \mathrm{NaCl}, 4.7 \mathrm{mM} \mathrm{KCl}, 1.28 \mathrm{mM} \mathrm{CaCl}_{2}, 1.2 \mathrm{mM}$ $\mathrm{KH}_{2} \mathrm{PO}_{4}, 1.2 \mathrm{mM} \mathrm{MgSO}$, $10 \mathrm{mM} \mathrm{NaHCO} 3,10 \mathrm{mM}$ Hepes free acid, $0.5 \%(\mathrm{w} / \mathrm{v})$ bovine serum albumin, 1.1 $\mathrm{mM}$ glucose, $\mathrm{pH}$ 7.4) was carefully added to each well [11]. Cells were thereafter incubated $(n=8)$ for $20 \mathrm{~min}$ at $37^{\circ} \mathrm{C}$ with $1 \mathrm{ml}$ of test buffer supplemented with glucose $(5.6 \mathrm{mM})$ in the absence or presence of plant extract and alanine $(10 \mathrm{mM})$, used as positive control. The concentrations of plant extracts in the incubation medium were 50 and $100 \mu \mathrm{g} / \mathrm{ml}$. Following incubation, aliquots 
of buffer were removed from each well and stored at $-20^{\circ} \mathrm{C}$ for the determination of insulin level by radioimmunoassay (RIA) as previously described by [12] using guinea-pig anti-porcine insulin antiserum and crystalline rat insulin standard.

\subsection{Evaluation of Cell Viability}

BRIN-BD11 cell viability was determined using a modified neutral red assay [13]. Following removal of the aliquots for measurement of acute insulin secretion, the cells were washed once with Krebs Ringer Bicarbonate Buffer supplemented with $0.1 \%$ BSA (KRB) and incubated for $2 \mathrm{~h}$ with $1 \mathrm{ml}$ neutral red solution $(50 \mu \mathrm{g}$ neural red dissolved in $50 \mu \mathrm{l}$ DMSO and made up $200 \mathrm{ml}$ with KRB). After washing (as described above), $1 \mathrm{ml}$ of 49:50:1 distilled water:ethanol:glacial acetic acid solution was added and the plates were gently agitated for 15 min. Absorbance was read using a spectrophotometer (Novaspec; LKB Biochrom, Cambridge, London) at 540 $\mathrm{nm}$ and the mean absorbance for each test solution calculated. Results were expressed as a percentage of control (incubations without test agent) giving percentage cell viability after $20 \mathrm{~min}$ exposure to test agent.

$$
\begin{aligned}
& \text { Cell viability }(\%) \\
& =\frac{\text { Mean absorbance for test incubation }}{\text { Mean absorbance for control incubation }} \times 100
\end{aligned}
$$

\subsection{Statistical Analysis}

Results are expressed as mean \pm S.E.M. Analyses were performed using the unpaired Student's t test and one-way analysis of variance (ANOVA) followed by Dunnett'st-test for comparisons. Results were considered significant if $\mathrm{p}<0.05$.

\section{RESULTS}

\subsection{Intestinal Glucose Absorption}

Figure 1 shows the effect of $B$. ndellensis extract on intestinal absorption of glucose. The percent of glucose absorbed across the intestine was almost constant during the whole period of perfusion with glucose solution. The supplementation of the perfusion medium with $80 \%$ ethanol extract of $B$. ndellensis did not affect the amount of absorbed glucose. However, ouabain which is an inhibitor of glucose transport across the small intestine significantly $(p<0.001)$ decreased the glucose absorption during the whole perfusion period compared with the control group.

\subsection{Gastrointestinal Motility}

Gastrointestinal (GI) motility was evaluated by using
Barium sulphate milk technique. The total length of the intestine $(96.99 \pm 3.77 \mathrm{~cm})$ in rats treated with the extract of $B$. ndellensis is not significantly different as compared with the control $(99.48 \pm 5.26 \mathrm{~cm})$. The length of small intestine traversed by $\mathrm{BaSO}_{4}$ was significantly $(\mathrm{p}<0.01)$ lower in rats pre-treated with extract $(1.25 \mathrm{~g} / \mathrm{kg} \mathrm{bw})$ compared with control (Table 1).

\subsection{Insulin Secretion in Vitro and Cell Viability}

The $80 \%$ ethanol extract of $B$. ndellensis at concentrations of 50 and $100 \mu \mathrm{g} / \mathrm{ml}$ exerted a dose-dependent stimulatory effect on insulin secretion from BRIN-BD11 cells in vitro (Figure 2(b)). At the concentration of 50 $\mu \mathrm{g} / \mathrm{ml}$, the extract did not show any significant stimulatory effect on insulin release from clonal cells compared with the glucose control $(1.88 \pm 0.40$ vs $1.65 \pm 0.09$ $\mathrm{ng} / 106$ cells, $20 \mathrm{~min})$. At a concentration of $100 \mu \mathrm{g} / \mathrm{ml}$, the extract significantly $(\mathrm{p}<0.001)$ potentiated insulin release in the presence of $5.6 \mathrm{mM}$ glucose $(3.50 \pm 0.32$ ng/106 cells, $20 \mathrm{~min}$ ) as compared with basal insulin release with glucose $(1.65 \pm 0.09 \mathrm{ng} / 106$ cells, $20 \mathrm{~min})$. Alanine $(10 \mathrm{mM})$ used as positive control, significantly

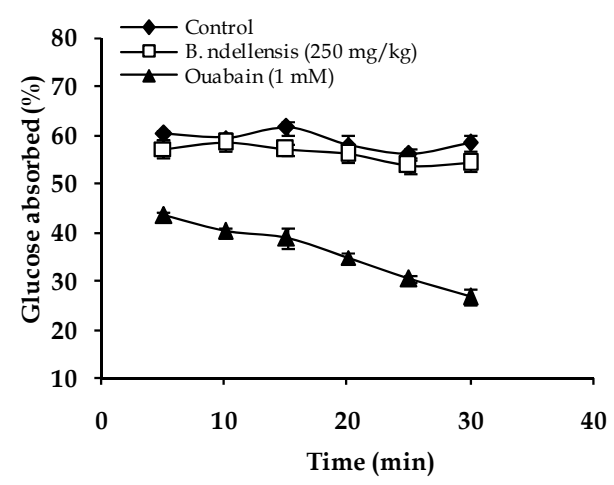

Figure 1. Effect of $80 \%$ ethanol extract of Bridelia ndellensis on intestinal absorption of glucose in nondiabetic rats. Results are expressed as percentage of absorbed glucose (mean \pm S.E.M., $\mathrm{n}=6$ ), calculated from the amount of glucose in solution before and after perfusion. ${ }^{* * *} \mathrm{p}<0.001$ significantly different from control group.

Table 1. Effect of $80 \%$ ethanol extract of Bridelia ndellensis on gastrointestinal motility in nondiabetic rats.

\begin{tabular}{ccccc}
\hline Group & $n$ & $\begin{array}{c}\text { GI total length } \\
(\mathrm{cm})\end{array}$ & $\begin{array}{c}\text { Length traversed } \\
\text { by BaSO}\end{array}(\mathrm{cm})$ & $\begin{array}{c}\text { Percent length } \\
\text { traversed by } \\
\mathrm{BaSO}_{4}\end{array}$ \\
\hline Control & 6 & $99.48 \pm 5.26$ & $62.23 \pm 4.59$ & $62.75 \pm 5.76$ \\
$\begin{array}{c}\text { Extract } \\
(1.25 \mathrm{~g} / \mathrm{kg})\end{array}$ & 7 & $96.99 \pm 3.77$ & $45.96 \pm 5.46^{* *}$ & $47.49 \pm 4.53^{* *}$ \\
\hline
\end{tabular}

Values are mean \pm S.E.M., n: number of animals per group. GI: gastrointestinal tract ${ }^{* *} \mathrm{p}<0.01$ significantly different from control group. 
$(\mathrm{p}<0.001)$ stimulated insulin release $(7.5 \pm 0.51 \mathrm{ng} / 106$ cells, $20 \mathrm{~min}$ ) from BRIN-BD11 cells.

At a concentration of $100 \mu \mathrm{g} / \mathrm{ml}$, cell viability during the test period was significantly diminished $(p<0.01)$ as evaluated by neutral red assay $(87.51 \pm 4.39$ vs $99.99 \% \pm$ $1.70 \%)$. Such an effect was not evident at lower concentration of the extract $(50 \mu \mathrm{g} / \mathrm{ml})$. Alanine $(10 \mathrm{mM}) \mathrm{did}$ not alter cell viability (Figure 2(a)).

\section{DISCUSSION}

The retardation of membrane-bound $\alpha$-glucosidase reaction and/or inhibition of passive glucose transport would successfully flatten the postprandial blood glucose excursions or reduce hyperglycaemia [14] and also, enhances intestinal motility and influences absorption in anesthetized rat [15]. In this study the $80 \%$ ethanol extract of $B$. ndellensis did not show any inhibitory effect

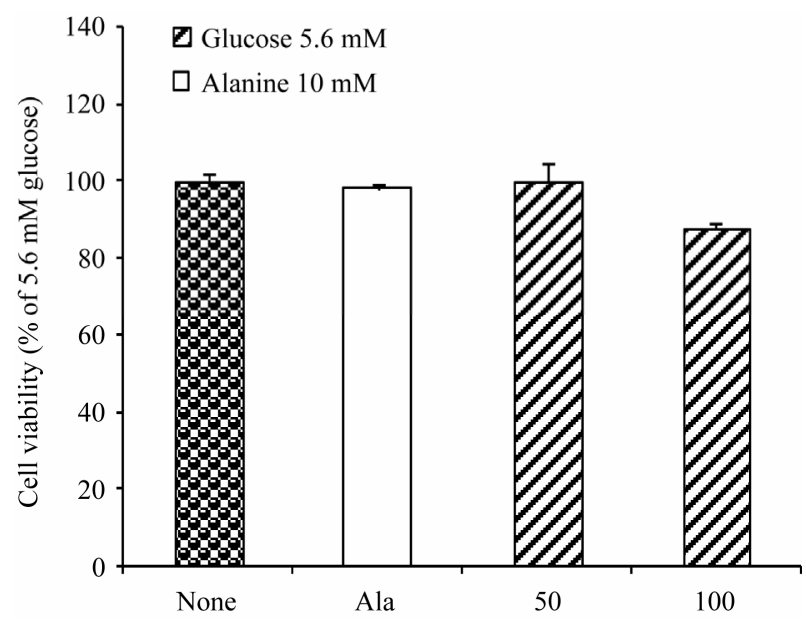

(a)

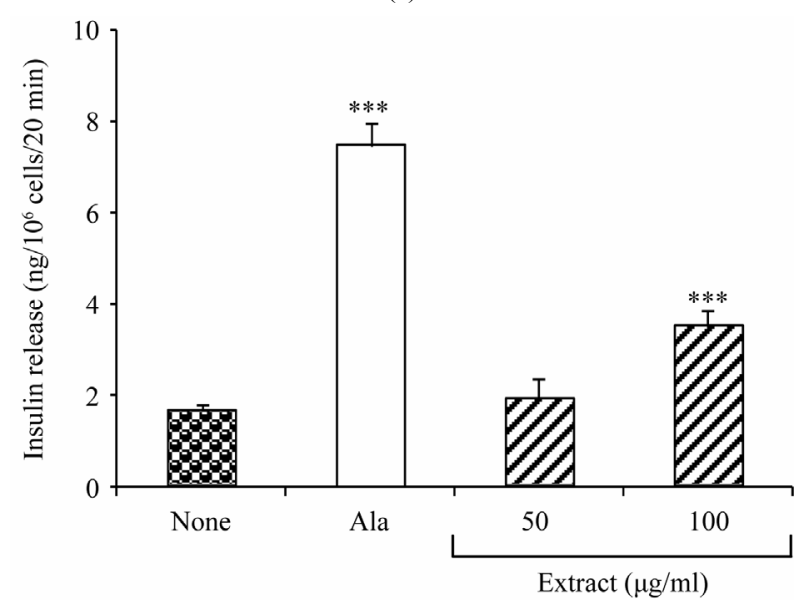

(b)

Figure 2. Acute effects of $80 \%$ ethanol extract of Bridelia ndellensis on BRIN-BD11 cell viability and insulin release in vitro. Values are mean \pm S.E.M., $\mathrm{n}=8 .{ }^{* *} \mathrm{p}<0.01$ and ${ }^{* * *} \mathrm{p}<$ 0.001 significantly different from the control group (glucose $5.6 \mathrm{mM}$ only). on glucose absorption in a perfused rat intestinal preparation. Moreover, the extract strongly inhibited the $\mathrm{BaSO}_{4}$-induced GI motility. Thus the hypoglycaemic effect of the extract in the glucose-fed rats suggests that its main mechanism may not be due to an inhibition of glucose transport across the intestine or an excretion by faeces. It may be presumed that the glucose-lowering effect of the extract as previously reported [5] is achieved via an extra-intestinal action. Our results showed that $80 \%$ ethanol extract of B. ndellensis (50 and $100 \mu \mathrm{g} / \mathrm{ml}$ ) exerted a dose-dependent stimulatory effect on glucoseinduced insulin secretion from BRIN-BD11 cells in vitro. Similar results have been reported with the extract of Sambucus nigra [16] and Terminalia bellirica [17]. Phosphodiesterase (PDE) inhibitors such as IBMX [18] increase cAMP concentration and potentiate insulin secretion initiated by other agents. Islet $\beta$-cells expressed many types of PDEs, and the inhibition of type III (cAMP-inhibited) provokes a particularly strong insulinreleasing effect [19]. A bio-guided fractionation of $B$. ndellensis ethanol extract has revealed the presence of quinovic acid glycosides. These compounds as well as the parent ethanol extract and the ethyl acetate fraction, strongly inhibited type I phosphodiesterase from snake venom [20]. Thus it is possible that the extract potentiate the insulin secretion by inhibiting the phosphosdiesterase activity and thereby prolonging the effect of cAMP. Such inhibition has also been reported with the arylpiperazine L-686,398, an oral hypoglycaemic agent [21]. On the other hand, the extract may stimulate insulin secretion through the activation of the ATP-sensitive $\mathrm{K}+$ channels pathway like sulfonylurea class of drugs which enhance insulin secretion by binding to sulfonylurea receptors on the $\beta$-cell, with subsequent closure of $\mathrm{K}^{+}$-ATP channels, followed by membrane depolarization and $\mathrm{Ca}^{2+}$ influx [22].

\section{CONCLUSION}

In conclusion, the present study has shown that the $80 \%$ ethanol extract of B. ndellensis stem bark did not show any inhibiting effects on glucose absorption. However, this plant extract possesses an insulinotropic effect which, in part justify its antihyperglycemic effects. Further work is required to isolate and characterize the active principles present in this plant for the development of potential new drugs against diabetes.

\section{ACKNOWLEDGEMENTS}

This research was supported by the International Foundation for Science (IFS), Stockholm, Sweden, the Organisation for Prohibition of Chemical Weapons (OPCW), The Hague, The Netherlands and the Committee on Scientific and Technological Cooperation of Islamic Conference (COMSTECH), Islamabad, Pakistan, through a grant $(\mathrm{F} /$ 
3341-1) to Dr. S. D. Sokeng. We thank Dr. B. Kengue, National Herbarium, Yaounde, Cameroon, for the identification and collection of plant materials.

\section{REFERENCES}

[1] Kwon, Y.I., Apostolidis, E. and Shetty, K. (2008) In vitro studies of egg-plant (Solanum melongena) phenolics as inhibitors of key enzymes relevant for type 2 diabetes and hypertension. Bioresource Technology, 99, 2981-2988. doi:10.1016/j.biortech.2007.06.035

[2] International Diabetes Federation (2006) Diabetes atlas, 3rd Edition. http://www.eatlas.idf.org

[3] World Health Organization (1980) Expert committee on diabetes mellitus. WHO Technical Report, Series No. 646, Geneva.

[4] Weragoda, P.B. (1980) Some questions about the future of traditional medicine in developing countries. Journal of Ethnopharmacology, 2, 193-194. doi:10.1016/0378-8741(80)90015-X

[5] Sokeng, S.D., Rokeya, B., Mostafa, M., Nahar, N., Mosihuzzaman, M., Ali, L. and Kamtchouing, P. (2005) Antihyperglycemic effect of Bridelia ndellensis ethanol extract and fractions in streptozotocin-induced diabetic rats. African Journal of Traditional Complementary and Alternative Medicines, 2, 94-102. http://hdl.handle.net/1807/9193

[6] Kamtchouing, P., Sokeng, S.D., Moundipa, P.F., Watcho, P., Jatsa, H.B. and Lontsi, D. (1998) Protective role of Anacardium occidentale extract against streptozotocininduced diabetes in rats. Journal of Ethnopharmacology, 62, 95-99. doi:10.1016/S0378-8741(97)00159-1

[7] WHO (2002) Traditional medicine strategy 2002-2005. World Health Organization, Geneva, 74 Pages. www.who.int/medicinedocs/fr/d/Js2297e

[8] Swintosky, J.V. and Pogonowskawala, E. (1982) The insitu rat gut technique. Pharmacy International, 3, 163167.

[9] Barnes, C.D. and Eltherington, L.G. (1973) Drug dosage in lab animals; a handbook. 2nd Edition, University of California Press, Berkeley, 177 Pages.

[10] Sokeng, S.D., Rokeya, B., Hannan, J.M.A., Junaida, K., Zitech, P., Ali, L., Ngounou, G., Lontsi, D. and Kamtchouing, P. (2007) Inhibitory effect of Ipomoea aquatic extracts on glucose absorption using a perfused rat intestinal preparation. Fitoterapia, 78, 526-529. doi:10.1016/j.fitote.2007.06.011

[11] McClenaghan, N.H., Barnett, C.R., Ah-Sing, E., AbdelWahab, Y.H., O'Harte, F.P., Yoon, T.W., Swanston-Flatt,
S.K. and Flatt, P.R. (1996) Characterisation of a novel glucose responsive insulin secreting cell line, BRIN BD11, produced by electrofusion. Diabetes, 45, 1132-1140. doi:10.2337/diab.45.8.1132

[12] Flatt, P. and Bailey, C.J. (1981) Abnormal plasma glucose and insulin response in heterozygous lean $(o b /+)$ mice. Diabetologia, 20, 573-577. doi:10.1007/BF00252768

[13] Hunt, S.M., Chrznowska, C., Barnett, C.R., Brand, H.N. and Fawell, J.K. (1987) A comparison of in vitro cytotoxicity assays and their application to water samples. Alternatives to Laboratory Animals, 15, 20-29.

[14] Toeller, M. (1994) Alpha-glucosidase inhibitors in diabetes: Efficacy in NIDDM subjects. European Journal of Clinical Investigation, 24, 31-35. doi:10.1111/j.1365-2362.1994.tb02253.x

[15] Sababi, M. and Bengtsson, U.H. (2001) Enhance intestinal motility influences absorption in anesthetized rat. Acta Physiologica Scandinavica, 172, 115-122. doi:10.1046/j.1365-201X.2001.00849.x

[16] Gray, A.M., Abdel-Wahab, Y.H. and Flatt, P.R. (2000) The traditional plant treatment, Sambucus nigra (elder), Exhibits sulin-Like and Insulin-releasing actions in vitro. Journal of Nutrition, 130, 15-20.

[17] Kasabri, V., Flatt, P.R. and Abdel-Wahab, Y.H. (2010) Terminalia bellirica stimulates the secretion and action of insulin and inhibits starch digestion and protein glycation in vitro. British Journal of Nutrition, 103, 212-217. doi:10.1017/S0007114509991577

[18] Mishra, A. and Joy, K.P. (2006) 2-Hydroxyestradiol-17betaInduced oocyte maturation: involvement of cAMP-protein kinase A and okadaic acid-sensitive protein phosphatases, and their interplay in oocyte maturation in the catfish Heteropneustes fossilis. Journal Experimental Biology, 209, 2567-2575. doi:10.1242/jeb.02270

[19] Nattrass, M. and Bailey, C.J. (1999) New agents for Type 2. Best Practice \& Research Clinical Endocrinology \& Metabolism, 13, 309-329. doi:10.1053/beem.1999.0023

[20] Mostafa, M., Nahar, N, Mosihuzzaman, M., Sokeng, S.D., Fatima, N., Atta-ur-Rahman and Choudhary, I.M. (2006) Phosphodiesterase-I inhibitor quinovic acid glycosides from Bridelia ndellensis. Natural Product Research, 20, 686-692. doi:10.1080/14786410600661658

[21] Leibowitz, M.D., Biswas, C., Brady, E.J., Conti, M., Culliman, C.A., Hayes, N.S., Manganielle, V.C., Saperstein, R., Wang, L., Zafian, P.T. and Berger, J. (1995) A novel insulin secretagogue is a phosphodiesterase inhibitor. Diabetes, 44, 66-74. doi:10.2337/diab.44.1.67

[22] Gribble, F.M. and Reimann, F. (2003) Sulphonylurea action revisited: The post-cloning era. Diabetologia, 46, 875-891. doi:10.1007/s00125-003-1143-3 